\title{
Analisa Penjualan Produk Asuransi Jiwa Unitlink Bancassurance PT Commonwelath Life Dengan Metode Algoritma Apriori
}

\author{
${ }^{1}$ Melan Susanti, ${ }^{2}$ Khaqul Aziz \\ ${ }^{1,2}$ Sekolah Tinggi Manajemen Informatika dan Komputer Nusa Mandiri \\ e-mail: ${ }^{1}$ melan.msu@ nusamandiri.ac.id, ${ }^{2}$ khaqul.aziz@ gmail.com

\begin{tabular}{ccc}
\hline Diterima & Direvisi & Disetujui \\
$15-12-2019$ & $16-12-2019$ & $17-12-2019$ \\
\hline
\end{tabular}

\begin{abstract}
Abstrak - PT Commonwealth Life adalah salah satu perusahaan yang memiliki berbagai jenis produk dari berbagai jenis bisnis untuk pelanggan. Pelanggan merupakan kunci sukses dalam suatu usaha atau bisnis dalam menghadapi lingkungan bisnis yang kompetitif. Untuk menjaga penciptaan laba, maka perusahaan harus mengetahui apa yang menjadi kebutuhan pelanggan dan juga dapat menciptakan inovasi produk baru sebagai bentuk kepedulian terhadap pelanggan dan dapat menentukan produk mana yang paling diminati pelanggan. Untuk dapat menentukan produk mana yang paling diminati pelanggan, sebenarnya dapat menggunakan perhitungan secara manual. Namun banyaknya penjualan yang dilakukan setiap tahun, membuat data semakin banyak dan menumpuk, sehingga memerlukan waktu yang tidak sebentar untuk dapat menentukan atau menemukan produk mana yang paling banyak diminati oleh pelanggan dan memberikan kontribusi laba tertinggi bagi perusahaan, sehingga perlu dilakukan perhitungan dengan metode algoritma apriori untuk pendekatan asosiasi. Hasil yang didapatkan dari penelitian ini adalah rule yang dapat digunakan untuk membantu menentukan rekomendasi penciptaan produk secara lebih tepat, yaitu dengan menghasilkan 3 aturan asosiasi final ketika menggunakan minimum support $30 \%$ dan minimum confidence $70 \%$.
\end{abstract}

Kata Kunci: Algoritma Apriori, Penjualan Produk, Asuransi

\begin{abstract}
PT Commonwealth Life is one company that has various types of products from various types of businesses for customers. Customers are the key to success in a business or business in the face of a competitive business environment. To maintain profit creation, the company must know what the customer's needs are and can also create new product innovations as a form of customer care and be able to determine which products the customer is most interested in. To be able to determine which products are most interested in customers, you can actually use manual calculations. But the number of sales made every year, making more and more data pile up, so that it takes a long time to be able to determine or find which products are the most desirable by customers and contribute the highest profit to the company, so it needs to be calculated by the a priori algorithm method for the association approach. The results obtained from this study are rules that can be used to help determine product creation recommendations more precisely, namely by producing 3 final association rules when using a minimum support of $30 \%$ and a minimum of $70 \%$ confidence.
\end{abstract}

Keywords: A priori Algorithms, Product Sales, Insurance

\section{PENDAHULUAN}

Pendapatan suatu perusahaan berasal dari pelanggan, oleh karena itu diperlukan upaya untuk mengelola pelanggan dengan baik dan tepat. Pengelolaan pelanggan dalam hal ini adalah memperlakukan pelanggan sesuai dengan kontribusinya terhadap kelangsungan hidup perusahaan yaitu penciptaan laba. Pelanggan merupakan kunci sukses dalam suatu usaha atau bisnis dalam menghadapi lingkungan bisnis yang kompetitif. Untuk menjaga penciptaan laba, maka perusahaan harus mengetahui apa yang menjadi kebutuhan Pelanggan dan juga dapat menciptakan inovasi produk baru sebagai bentuk kepedulian terhadap Pelanggan.

Untuk dapat menentukan produk mana yang paling diminati pelanggan, sebenarnya dapat menggunakan perhitungan secara manual. Namun banyaknya penjualan yang dilakukan setiap tahun, membuat data semakin banyak dan menumpuk, sehingga memerlukan waktu yang tidak sebentar untuk dapat menentukan atau menemukan produk mana yang paling banyak diminati oleh Pelanggan dan memberikan kontribusi laba tertinggi bagi perusahaan. Dalam hal ini PT. Commonwealth Life 
memiliki berbagai jenis produk dari berbagai jenis bisnis. Khusus dalam bancassurance unitlink contohnya, transaksi yang terjadi dalam satu tahun berjumlah ribuan, hal ini menyebabkan sulitnya jika dilakukan perhitungan manual.

Pemanfaatan data yang ada di dalam sistem informasi untuk menunjang kegiatan pengambilan keputusan, tidak cukup hanya mengandalkan data operasional saja, diperlukan suatu analisis data untuk menggali potensi-potensi informasi yang ada. Para pengambil keputusan berusaha untuk memanfaatkan gudang data yang sudah dimiliki untuk menggali informasi yang berguna membantu mengambil keputusan, hal ini mendorong munculnya cabang ilmu baru untuk mengatasi masalah penggalian informasi atau pola yang penting atau menarik dari data dalam jumlah besar, yang disebut dengan data mining (Badrul, 2016).

Transaksi yang sering terjadi setiap hari sangat sulit sekali jika dilakukan oleh sarana manual karena itu penggunaan komputer dibutuhkan untuk mengatasinya. Komputer ini setiap waktu mengumpulkan dan mengolah data yang ada di tiap bagian perusahaan. Data-data yang dikumpulkan biasanya sering diperlakukan hanya sebagai simpanan atau rekaman perusahaan sehingga tidak memiliki nilai lebih untuk kemajuan usaha. Banyaknya persaingan di dunia bisnis, menuntut perusahaan untuk menemukan strategi yang dapat meningkatkan penjualan produk. Strategi ini sebenarnya bisa diperoleh dari hasil analisa rekaman data yang ada di komputer. Koleksi rekaman data yang dianalisa dengan metode atau aturan yang tepat dapat menghasilkan pengetahuan baru atau informasi yang berguna, misalnya berupa pola hubungan (asosiasi) atau keterkaitan yang terjadi pada data terutama data penjualan produk (Mulyana, 2014).

Data transaksi penjualan adalah salah satu hal yang bisa dimanfaatkan untuk suatu pengambilan keputusan bisnis. Kebanyakan data transaksi penjualan tidak dimanfaatkan kembali, dan hanya disimpan saja sebagai arsip serta hanya dijadikan untuk pembuatan suatu laporan penjualan. Data mining adalah salah satu ilmu yang dapat diterapkan dalam, kasus seperti ini. Transksi penjualan yang tidak dimanfaatkan dengan baik tersebut bisa digali dan diolah kembali menjadi suatu informasi yang bermanfaat dengan menggunakan teknik data mining (Djamaludin \& Nursikuwagus, 2017).

Berdasarkan latar belakang masalah di atas, maka penulis ingin melakukan penelitian dengan menggunakan algoritma apriori untuk dapat membantu management untuk mengelola data secara tepat dan akurat.

\section{a. Data Mining}

Data Mining adalah serangkaian proses untuk menggali nilai tambah berupa informasi yang selama ini tidak diketahui secara manual dari suatu basis data. Informasi yang dihasilkan diperoleh dengan cara mengekstraksi dan mengenali pola yang penting atau menarik dari data yang terdapat pada basis data. Data mining terutama digunakan untuk mencari pengetahuan yang terdapat dalam basis data yang besar sehingga sering disebut Knowledge Discovery Database (KDD (Vulandari, 2017). Pada proses Knowledge Discovery Database (KDD) terdapat beberapa fase yaitu sebagai berikut :

1. Seleksi Data (Selection)

Selection (seleksi/pemilihan) data dari merupakan sekumpulan data operasional perlu dilakukan sebelum tahap penggalian informasi dalam Knowledge Discovery Database (KDD) dimulai. Data hasil seleksi yang akan digunakan untuk proses data mining, disimpan dalam suatu berkas, terpisah dari basis data operasional.

2. Pemilihan Data (Preprocessing/Cleaning)

Proses Preprocessing mencakup antara lain membuang duplikasi data, memeriksa data yang inkonsisten, dan memperbaiki kesalahan pada data, seperti kesalahan cetak (tipografi). Juga dilakukan proses enrichment, yaitu proses "memperkaya" data yang sudah ada ada dengan data atau informasi lain yang relevan dan diperlukan untuk $K D D$, seperti data atau informasi eksternal.

3. Transformasi (Transformation)

Pada fase ini yang dilakukan adalah mentransformasi bentuk data yang belum memiliki entitas yang jelas kedalam bentuk data yang valid atau siap untuk dilakukan proses Data Mining.

4. Data Mining

Pada fase ini yang dilakukan adalah menerapkan algoritma atau metode pencarian pengetahuan.

5. Interpretasi/Evaluasi (Interpretation/Evaluation) Pada fase terakhir ini yang dilakukan adalah proses pembentukan keluaran yang mudah dimengerti yang bersumber pada proses Data Mining pola informasi. (Nofriansyah \& Nurcahyo, 2015)

\section{b. Algoritma Apriori}

Algoritma apriori termasuk jenis aturan asosiasi pada data mining. Aturan yang menyatakan asosiasi antara beberapa atribut sering disebut affinity analysis atau market basket analysis. (Thoriq Muhammad \& Nurhadiyono, 2014).

Algoritma apriori termasuk jenis aturan asosiasi pada data mining, Algoritma Apriori yangbertujuan untuk menemukan frequent item sets dijalankan pada sekumpulan data. Analaisis Apriori didefenisikan suatu proses untuk menemukan semua aturan apriori yang memenuhi syarat minimum 
untuk support dan syarat minimum untuk confidence (Pane, 2013).

\section{c. Analisis Asosiasi}

Analisis asosiasi atau association rule mining adalah teknik data mining untuk menemukan aturan suatu kombinasi item. Salah satu tahap analisis asosiasi yang menarik perhatian banyak peneliti untuk menghasilkan algoritma yang efisien adalah analisis pola frekuensi tinggi (frequent pattern mining) (Rezkiani, 2016)

Analisis asosiasi digunakan untuk menemukan pola yang menggambarkan kekuatan hubungan fitur dalam data. Pola yang ditemukan biasanya merepresentasikan bentuk aturan implikasi atau subset fitur. Tujuannya adalah untuk menemukan pola yang menarik dengan cara yang efisien (Suyanto, 2017).

Penting tidaknya suatu asosiasi dapat diketahui dengan dua tolak ukur, yaitu : support dan confidence. Support (nilai penunjang) adalah persentase kombinasi item tersebut dalam database, sedangkan confidence (nilai kepastian) adalah kuatnya hubungan antar item dalam aturan asosiasi.

Metode dasar analisis asosiasi terbagi menjadi dua tahap :

1. Analisa pola frekuensi tinggi

Tahap ini mencari kombinasi item yang memenuhi syarat minimum dari nilai support dalam database. Nilai support sebuah item diperoleh dengan rumus berikut:

Support $(A)=\frac{\Sigma \text { Transaksi yang mengandung } A}{\Sigma \text { Transaksi }} * 100 \%$

Sedangkan nilai support dari 2 item diperoleh dari rumus berikut:

$\operatorname{Support}(A, B)=\frac{\sum \text { Transaksi yang mengandung } A, B}{\sum \text { Transaksi }} * 100 \%$

2. Pembentukan aturan assosiatif

Setelah semua pola frekuensi tinggi ditemukan, barulah dicari aturan assosiatif yang memenuhi syarat minimum untuk confidence dengan menghitung confidence aturan assosiatif $\mathrm{A} \rightarrow \mathrm{B}$. Nilai confidence dari aturan $\mathrm{A} \rightarrow \mathrm{B}$ diperoleh dari rumus berikut: Transaksi yang mengandung $\mathrm{A}, \mathrm{B} \sum$

Confidence $(B \mid A)=\frac{\sum \text { Transaksi yang mengandung } A, B}{\Sigma \text { Transaksi }} * 100 \%$

\section{METODE PENELITIAN}

Penelitian merupakan suatu penyelidikan atau usaha yang sistematis, terkendali, empiris, teliti dan kritis terhadap fenomena-fenomena untuk mencari suatu fakta-fakta, teori baru, hipotesis dan kebenaran dengan menggunakan langkah-langkah tertentu agar ditemukan jawaban ilmiah terhadap suatu masalah (Sujarweni, 2014).

Instrumen penelitian disebut juga sebagai alat bantu untuk mengumpulkan data dalam melakukan penelitian. Instrumen-instrumen penelitian yang dibutuhkan dalam melakukan penelitian ini adalah :

1. Instrumen Pokok

a. Narasumber

Narasumber adalah seorang yang dimanfaatkan untuk memberikan informasi tentang situasi dan kondisi latar penelitian. Dalam penelitian ini, orang yang berperan sebagai narasumber adalah Nasional Sales Head, dan personil dari Data Management.

b. Penulis atau Peneliti

Penulis atau peneliti dalam penelitian termasuk ke dalam instrumen pokok karena penulis atau peneliti berinteraksi langsung dengan narasumber untuk mendapatkan informasi yang dibutuhkan dalam penelitian.

2. Instrumen Pendukung

Pedoman Wawancara

Dalam penelitian ini, penulis atau peneliti melakukan wawancara kepada narasumber untuk mendapatkan informasi sehingga dibutuhkan pedoman wawancara. Pedoman wawancara ini berisi pertanyaan-pertanyaan yang dibuat dan pertanyaan-pertanyaan tersebut akan diajukan kepada narasumber.

\section{Metode Pengumpulan Data, Populasi dan Sample Penelitian}

\section{Metode Pengumpulan Data}

Menurut (Sugiyono, 2017) "Pengumpulan data merupakan langkah yang paling strategis dalam penelitian, karena tujuan utama dari penelitian adalah mendapatkan data. Tanpa mengetahui teknik pengumpulan data, maka peneliti tidak akan mendapatkan data yang memenuhi standar data yang di tetapkan".

Adapun teknik pengumpulan data yang dilakukan dalam analisa penjualan produk asuransi jiwa pada PT. Commonwealth Life dengan metode sebagai berikut :

a. Metode Observasi

Pada penelitian ini, penulis melakukan pengamatan secara langsung terhadap pencatatan data transaksi penjualan pada bagian Operational Services yang khusus mencatat transaksi produk asuransi unitlink.

b. Metode Wawancara

Dalam tahap ini penulis melakukan wawancara secara langsung dan mengajukan beberapa pertanyaan mengenai proses pencatatan data transaksi penjualan beserta atribut-atribut yang digunakan dalam pembuatan laporan transaksi tersebut. 
c. Studi Pustaka

Studi pustaka dilakukan guna menunjang metode pengumpulan data wawancara dan observasi yang telah dilakukan. Studi pustaka dilakukan dengan cara mengumpulkan informasi yang berupa dokumen-dokumen yang dibutuhkan dalam Analisa Penjualan produk asuransi di PT Commonwealth Life.

\section{Populasi}

Populasi bukan hanya seseorang, tetapi juga obyek dan benda yang berada disekitar. Populasi juga bukan hanya sekedar jumlah yang ada pada obyek maupun subyek yang dipelajari. Populasi yang digunakan berupa beberapa produk asuransi unitlink bancassurance $P T$. Commonwealth Life yang sudah dibeli selama 6 bulan dari bulan januari sampai bulan juni.

3. Sampel Penelitian

$$
\text { Apabila peneliti melakukan }
$$

penelitian terhadap populasi yang benar, sementara peneliti ingin meneliti tentang populasi tersebut dan peneliti memilki keterbatasan dana, tenaga dan waktu, maka peneliti menggunakan teknik pengambilan sampel. Sampel yang digunakan hanya dilihat dari tiga produk asuransi jiwa unitlink Bancassurance yang banyak dibeli disetiap bulannya selama 6 bulan.

\section{Metode Analisis Data}

Menentukan metode analisa data dapat dilihat dari tujuan dan jenis penelitian yang dilakukan dan model data yang ada. Metode analisis data berdasarkan teknik pengolahannya dibagi menjadi dua, yaitu :

a. Analisa Deskriptif

Statistik deskriptif berusaha untuk menggambarkan berbagai karakteristik data yang berasal dari suatu sampel. Statistik deskriptif seperti mean, median, modus, presentil, desil, quartile, dalam bentuk analisis angka maupun gambar/diagram. Dalam analisis deskriptif diolah pervariabel.

b. Analisis Inferensi

Statistic inferensial berusaha membuat berbagai inferensi terhadap sekumpulan data yang berasal dari suatu sampel. Tindakan inferensi tersebut seperti melakukan perkiraan, peramalan, pengambilan keputusan dari dua variable atau lebih. Dalam analisis inferensi yang diolah adalah dua variable atau lebih yang diadukan misalnya analisis hubungan, pengaruh, perbedaan antar variable atau lebih.

\section{HASIL DAN PEMBAHASAN}

Tahap dalam menganalisa data dengan algoritma apriori pada penjualan produk asuransi jiwa unitlink dimulai dengan menyeleksi dan membersihkan data - data yang akan dianalisis, kemudian dicari semua jenis item produk asuransi jiwa unitlink yang ada didalam transaksi penjualan. Selanjutnya dicari jumlah setiap item yang ada pada transaksi penjualan. Berdasarkan data penjualan produk asuransi jiwa unitlink selama 6 bulan, didapatkan pola transaksi dengan menganalisis 3 jenis produk asuransi jiwa unitlink yang paling banyak terjual setiap bulannya.

Tabel 1. Daftar Nama Produk Asuransi Unitlink

\begin{tabular}{|c|c|}
\hline No & Nama Produk \\
\hline 1 & Commlink Premier \\
\hline 2 & Elite Link \\
\hline 3 & Maxiwealth Link IDR \\
\hline 4 & Maxiwealth Link USD \\
\hline 5 & Commlink IDR \\
\hline 6 & Commlink AUD \\
\hline 7 & Commlink Signature IDR \\
\hline 8 & Commlink Signature USD \\
\hline
\end{tabular}

Sumber : PT. Commonwealth Life (2018)

Tabel 2. PolaTransaksi Penjualan Produk

\begin{tabular}{|c|c|}
\hline Bulan & Item Set \\
\hline Januari & $\begin{array}{c}\text { Maxiwealth Link IDR, Maxiwealth Link } \\
\text { USD, Elite Link }\end{array}$ \\
\hline Februari & $\begin{array}{c}\text { Maxiwealth Link IDR, Maxiwealth Link } \\
\text { USD, Elite Link }\end{array}$ \\
\hline Maret & $\begin{array}{c}\text { Maxiwealth link IDR, Elite Link, } \\
\text { Maxiwealth Link USD }\end{array}$ \\
\hline April & $\begin{array}{c}\text { Maxiwealth link IDR, Elite Link, } \\
\text { Commlink Premier }\end{array}$ \\
\hline Mei & $\begin{array}{c}\text { Maxiwealth link IDR, Elite Link, } \\
\text { Maxiwealth Link USD }\end{array}$ \\
\hline Juni & $\begin{array}{c}\text { Maxiwealth Link IDR, Maxiwealth Link } \\
\text { USD, Commlink Premier }\end{array}$ \\
\hline
\end{tabular}

Sumber : PT. Commonwealth Life (2018)

\section{Analisa Pola Frekuensi Tinggi}

Proses pembentukan $\mathrm{C}_{1}$ atau disebut dengan 1 itemset dengan jumlah minimum support $=30 \%$. Berikut merupakan perhitungan pembentukan 1 itemset :

Support (Commlink Premier)

$=\frac{\Sigma \text { Commlink Premier }}{\Sigma \text { Transaksi }} * 100 \%=\frac{46}{110} * 100 \%=41,818 \%$ 


\section{Support (Elite Link)}

$=\frac{\Sigma \text { Elite Link }}{\Sigma \text { Transaksi }} * 100 \%=\frac{72}{110} * 100 \%=65,455 \%$

Support (Maxiwealth IDR)

$=\frac{\Sigma \text { Maxiwealth } I D R}{\Sigma \text { Transaksi }} * 100 \%=\frac{105}{110} * 100 \%=95,455 \%$

Support (Maxiwealth USD)

$=\frac{\Sigma \text { Maxiwealth USD }}{\Sigma \text { Transaksi }} * 100 \%=\frac{69}{110} * 100 \%=62,727 \%$

Support (Commlink Single IDR)

$=\frac{\Sigma \text { Single IDR }}{\Sigma \text { Transaksi }} * 100 \%=\frac{4}{110} * 100 \%=3,636 \%$

Support (Commlink Single AUD)

$=\frac{\Sigma \text { Single AUD }}{\Sigma \text { Transaksi }} * 100 \%=\frac{11}{110} * 100 \%=10,000 \%$

Support (Signature IDR)

$=\frac{\Sigma \text { Signature IDR }}{\Sigma \text { Transaksi }} * 100 \%=\frac{21}{110} * 100 \%=19,091 \%$

Support (Signature USD)

$=\frac{\Sigma \text { Signature USD }}{\Sigma \text { Transaksi }} * 100 \%=\frac{14}{110} * 100 \%=12,727 \%$

Berikut merupakan hasil dari pembentukan 1 itemset :

Tabel 3. Hasil dari Pembentukan 1 Itemset

\begin{tabular}{|l|c|c|}
\hline \multicolumn{1}{|c|}{ Itemset } & Jumlah & Support \\
\hline Commlink Premier & 46 & $41.82 \%$ \\
\hline Elite Link & 72 & $65.45 \%$ \\
\hline Maxiwealth IDR & 105 & $85.45 \%$ \\
\hline Maxiwealth USD & 69 & $62.73 \%$ \\
\hline Commlink IDR & 4 & $3.64 \%$ \\
\hline Commlink AUD & 11 & $10.00 \%$ \\
\hline Signature IDR & 21 & $19.09 \%$ \\
\hline Signature USD & 14 & $12.73 \%$ \\
\hline
\end{tabular}

Proses pembentukan $\mathrm{C}_{2}$ atau disebut dengan 2 itemset dengan jumlah minimum support $=30 \%$. Berikut merupakan perhitungan pembentukan $\mathrm{C} 2$ atau 2 itemset :

\section{Support (Commlink Premier, Elite Link)}

$=\frac{\Sigma \text { Commlink Premier,Elite Link }}{\Sigma \text { Transaksi }} * 100 \%=\frac{32}{110} * 100 \%=29,091 \%$

Support (Commlink Premier, Maxi IDR)

$=\frac{\Sigma \text { Commlink Premier,Maxi IDR }}{\Sigma \text { Transaksi }} * 100 \%=\frac{45}{110} * 100 \%=40,909 \%$

Support (Commlink Premier, Maxi USD) $=\frac{\sum \text { Commlink Premier,Maxi USD }}{\Sigma \text { Transaksi }} * 100 \%=\frac{33}{110} * 100 \%=30,000 \%$

Support (Elite Link, Maxi IDR)

$=\frac{\text { EElite Link,Maxi IDR }}{\Sigma \text { Transaksi }} * 100 \%=\frac{67}{110} * 100 \%=60,909 \%$

Support (Elite Link, Maxi USD)

$=\frac{\text { EElite Link,Maxi USD }}{\Sigma \text { Transaksi }} * 100 \%=\frac{51}{110} * 100 \%=46,364 \%$

Support (Maxi IDR, Maxi USD)

$=\frac{\Sigma \text { Maxi IDR,Maxi USD }}{\Sigma \text { Transaksi }} * 100 \%=\frac{69}{110} * 100 \%=62,727 \%$

Berikut merupakan hasil dari pembentukan 2 itemset :

Tabel 4. Hasil dari Pembentukan 2 Itemset

\begin{tabular}{|l|c|c|}
\hline \multicolumn{1}{|c|}{ Itemset } & Jumlah & Support \\
\hline Commlink Premier, Elite Link & 32 & $29.09 \%$ \\
\hline $\begin{array}{l}\text { Commlink Premier, Maxi } \\
\text { IDR }\end{array}$ & $\mathbf{4 5}$ & $\mathbf{4 0 . 9 1 \%}$ \\
\hline $\begin{array}{l}\text { Commlink Premier, Maxi } \\
\text { USD }\end{array}$ & $\mathbf{3 3}$ & $\mathbf{3 0 . 0 0 \%}$ \\
\hline Elite Link, Maxi IDR & $\mathbf{6 7}$ & $\mathbf{6 0 . 9 1 \%}$ \\
\hline Elite Link, Maxi USD & $\mathbf{5 1}$ & $\mathbf{4 6 . 3 6 \%}$ \\
\hline Maxi IDR, Maxi USD & $\mathbf{6 9}$ & $\mathbf{6 2 . 7 3 \%}$ \\
\hline
\end{tabular}

Sumber : Hasil Penelitian (2018)

Proses pembentukan $\mathrm{C}_{3}$ atau disebut dengan 3 itemset dengan jumlah minimum support $=30 \%$. Berikut merupakan perhitungan pembentukan $\mathrm{C} 3$ atau 3 itemset :

Support (Commlink Premier, EliteLink, Maxi IDR)

$$
\begin{gathered}
=\frac{\sum \text { Commlink Premier, EliteLink, Maxi IDR }}{\sum \text { Transaksi }} * 100 \%=\frac{31}{110} * 100 \% \\
=28,182 \%
\end{gathered}
$$

Support (Commlink Premier, EliteLink, Maxi USD)

$=\frac{\Sigma \text { Commlink Premier, EliteLink, Maxi USD }}{\sum \text { Transaksi }} * 100 \%=\frac{26}{110} * 100 \%$

$$
=23,636 \%
$$

Support (Commlink Premier, Maxi IDR, Maxi USD)

$$
=\frac{\sum \text { Commlink Premier }, \text { Maxi IDR, Maxi USD }}{\sum \begin{array}{c}
\text { Transaksi } \\
=30,000 \%
\end{array}} * 100 \%=\frac{33}{110} * 100
$$

Support (EliteLink, Maxi IDR, Maxi USD)

$$
=\frac{\sum \text { EliteLink, Maxi IDR, Maxi USD }}{\sum \text { Transaksi }} * 100 \%=\frac{51}{110} * 100 \%
$$

Berikut merupakan hasil dari pembentukan 3 itemset : 
Tabel 5. Hasil dari Pembentukan 3 Itemset

\begin{tabular}{|l|c|c|}
\hline \multicolumn{1}{|c|}{ Itemset } & Jumlah & Support \\
\hline $\begin{array}{l}\text { Commlink Premier, Elite Link, } \\
\text { Maxi IDR }\end{array}$ & 31 & $28.18 \%$ \\
\hline $\begin{array}{l}\text { Commlink Premier, Elite Link, } \\
\text { Maxi USD }\end{array}$ & 26 & $23.64 \%$ \\
\hline $\begin{array}{l}\text { Commlink Premier, Maxi } \\
\text { IDR, Maxi USD }\end{array}$ & $\mathbf{3 3}$ & $\mathbf{3 0 . 0 0 \%}$ \\
\hline $\begin{array}{l}\text { Elite Link, Maxi IDR, Maxi } \\
\text { USD }\end{array}$ & $\mathbf{5 1}$ & $\mathbf{4 6 . 3 6 \%}$ \\
\hline
\end{tabular}

Sumber : Hasil Penelitian (2018)

\section{Pembentukan Aturan Asosiasi}

Setelah semua pola frekuensi tinggi ditemukan, baru dicari aturan asosiasi yang memenuhi syarat minimum Confidence dengan menghitung Confidence aturan asosiatif $\mathrm{A} \rightarrow \mathrm{B}$. Penulis menggunakan minimal Confidence $=70 \%$. Berikut merupakan perhitungan Confidence:

Confidence $=P($ Commlink Premier, Maxi IDR, Maxi USD)

$=\frac{\sum \text { Commlink Premier, } \text { Maxi IDR,Maxi USD }}{\sum \text { Commlink Premier }} * 100 \%=\frac{33}{46} *$

$100 \%=71,739 \%$

Confidence $=P($ Maxi IDR, Commlink Premier, Maxi USD)

$=\frac{\sum \text { Maxi IDR,Commlink Premier,Maxi USD }}{\sum \text { Maxi IDR }} * 100 \%=\frac{33}{105} *$

$100 \%=31,429 \%$

Confidence $=P($ Maxi USD, Commlink Premier Maxi IDR)

$=\frac{\sum \text { Maxi USD,Commlink Premier, }, \text { Maxi IDR }}{\sum \text { Maxi USD }} * 100 \%=\frac{33}{69} *$

$100 \%=47,826 \%$

Confidence $=P($ Elite Link, Maxi IDR, Maxi USD $)$

$=\frac{\sum \text { Elite Link,Maxi IDR,Maxi USD }}{\sum \text { Elite Link }} * 100 \%=\frac{51}{72} * 100 \%=$

$70.833 \%$

Confidence $=P($ Maxi USD, Elite Link, Maxi IDR $)$

$=\frac{\sum \text { Maxi USD,Elite Link,Maxi IDR }}{\sum \text { Maxi USD }} * 100 \%=\frac{51}{69} * 100 \%=$

$73,913 \%$

Confidence $=P($ Maxi IDR, Elite Link, Maxi USD $)$ $=\frac{\sum \text { Maxi IDR,Elite Link,Maxi USD }}{\sum \text { Maxi IDR }} * 100 \%=\frac{51}{105} * 100 \%=$

$48,571 \%$

Dari kombinasi 3 itemset yang telah ditemukan, dapat dilihat besarnya nilai support, dan confidence dari calon aturan asosiasi seperti tampak pada table berikut :

Tabel 6. Calon Aturan Asosiasi

\begin{tabular}{|l|c|c|}
\hline \multicolumn{1}{|c|}{ Aturan } & \multicolumn{2}{c|}{ Confidence } \\
\hline $\begin{array}{l}\text { Commlink Premier, Maxi IDR, Maxi } \\
\text { USD }\end{array}$ & $33 / 46$ & $71.739 \%$ \\
\hline $\begin{array}{l}\text { Maxi IDR, Commlink Premier, Maxi } \\
\text { USD }\end{array}$ & $33 / 105$ & $31.429 \%$ \\
\hline $\begin{array}{l}\text { Maxi USD, Commlink Premier, Maxi } \\
\text { IDR }\end{array}$ & $33 / 69$ & $47.826 \%$ \\
\hline Elite Link, Maxi IDR, Maxi USD & $51 / 72$ & $70.833 \%$ \\
\hline Maxi IDR, Elite Link, Maxi USD & $51 / 105$ & $48.571 \%$ \\
\hline Maxi USD, Elite Link, Maxi IDR & $51 / 69$ & $73.913 \%$ \\
\hline
\end{tabular}

Sumber : Hasil Penelitian (2018)

Berdasarkan dari calon aturan asosiasi pada Tabel 6 diatas, maka yang memenuhi minimal support $30 \%$ dan minimal confidence $70 \%$ adalah pada table berikut :

Tabel 7. Aturan Asosiasi Final

\begin{tabular}{|l|c|c|}
\hline \multicolumn{1}{|c|}{ Aturan } & Support & Confidence \\
\hline $\begin{array}{l}\text { Commlink Premier, Maxi } \\
\text { IDR, Maxi USD }\end{array}$ & $30.000 \%$ & $71.739 \%$ \\
\hline $\begin{array}{l}\text { Elite Link, Maxi IDR, Maxi } \\
\text { USD }\end{array}$ & $46.364 \%$ & $70.833 \%$ \\
\hline $\begin{array}{l}\text { Maxi USD, Elite Link, Maxi } \\
\text { IDR }\end{array}$ & $46.364 \%$ & $73.913 \%$ \\
\hline
\end{tabular}

Sumber : Hasil Penelitian (2018)

\section{KESIMPULAN}

Berdasarkan hasil pengumpulan dan analisis data dalam penelitian ini, maka di dapat kesimpulan bahwa, Strategi penjualan yang cocok pada pembahasan ini adalah memberikan rekomendasi produk terhadap kombinasi penjualan dengan nilai support $30 \%$ dan nilai confidence $70 \%$.

Menggunakan metode apriori dapat membantu dalam mengetahui produk yang paling banyak terjual, yang pada akhirnya dapat digunakan untuk menyusun strategi penjualan dan inovasi produk sejenis.

Hasil dari penelitian ini, aturan asosiasi final yang tertinggi adalah, jika membeli Maxiwealth USD, maka akan membeli Maxiwealth IDR dan Elite Link dengan nilai Support 46,364\% dan nilai confidence $73,913 \%$.

\section{REFERENSI}

Badrul, M. (2016). Algoritma Asosiasi Dengan Algoritma Apriori Untuk Analisa Data Penjualan. None, 12(2), 121-129. 
Djamaludin, I., \& Nursikuwagus, A. (2017). Analisis Pola Pembelian Konsumen Pada Transaksi Penjualan Menggunakan Algoritma Apriori. Simetris: Jurnal Teknik Mesin, Elektro Dan Ilmu Komputer, 8(2), 671. https://doi.org/10.24176/simet.v8i2.1566

Mulyana, H. (2014). Pemakaian Metode Asosiasi Dalam Data Mining Untuk Penjualan Lebih Dari Satu Jenis Produk Pada Perusahaan. Jurnal Pilar Nusa Mandiri, 10(1), 47-55.

Nofriansyah, D., \& Nurcahyo, G. W. (2015). Algoritma Data Mining dan Pengujian. Yogyakarta: Deepublish.

Pane, D. K. (2013). Implementasi Data Mining Pada Penjualan Produk Elektronik Dengan Algoritma Apriori ( Studi Kasus : Kreditplus ). Pelita Informatika Budi Darma, valume: I, 25-29. https://doi.org/2301-9425

Rezkiani, R. (2016). Implementasi Data Mining Dengan Algoritma Apriori Untuk Menentukan
Merek Sepatu Yang Diminati Pada Mahasiswa Pascasarjana Kelas 14.1a.01 Stmik Nusa Mandirijakarta. KNIT-2 Nusa Mandiri, 2(1), 49-INF.56.

Sugiyono. (2017). Metode Penelitian Kuantitatif, Kualitatif, dan $R \& D$. Bandung.

Sujarweni, V. W. (2014). Metodologi Penelitian. Yogyakarta: Pustakabarupress.

Suyanto. (2017). Data mining Untuk Klasifikasi dan Klasterisasi Data. In SpringerReference. https://doi.org/10.1007/SpringerReference_54 14

Thoriq Muhammad, A., \& Nurhadiyono, B. (2014). Penerapan Data Mining Pada Data Transaksi Penjualan Untuk Mengatur Penempatan Barang.

Vulandari, R. T. (2017). DATA MINING TEORI DAN APLIKASI RAPIDMINER. Yogyakarta: GAVA MEDIA. 